\title{
Kinetic analysis of the fermentative process of mead with the addition of cupuaçu (Theobroma grandiflorum) pulp
}

\author{
Análise cinética do processo fermentativo do hidromel com acréscimo de polpa de cupuaçu \\ (Theobroma grandiflorum) integral \\ Análisis cinético del proceso de fermentación de hidromiel com la adición de la pulpa de cupuaçu \\ (Theobroma grandiflorum) integral
}

Received: 10/12/2021 | Reviewed: 10/20/2021 | Accept: 10/22/2021| Published: 10/24/2021

\author{
Luiz Felipe Feitosa de Souza Lima \\ ORCID: https://orcid.org/0000-0002-4908-5207 \\ Universidade Federal do Amazonas, Brazil \\ E-mail: felipe.luiz.1@gmail.com \\ Thalita Caroline Lima Alves \\ ORCID: https://orcid.org/0000-0003-2255-2941 \\ Universidade Federal do Amazonas, Brazil \\ E-mail: thalitagw@gmail.com \\ Antonia Queiroz Lima de Souza \\ ORCID: https://orcid.org/0000-0001-5602-8617 \\ Universidade Federal do Amazonas, Brazil \\ E-mail: antoniaqueiroz@ufam.edu.br \\ Wenderson Gomes dos Santos \\ ORCID: https://orcid.org/0000-0002-3570-6340 \\ Universidade Federal do Amazonas, Brazil \\ E-mail: wenderson@ufam.edu.br
}

\begin{abstract}
Mead is historically one of the oldest drinks in the world. Its alcohol content can range from 4 to $14 \%$ and its formulation is basically honey, water, yeast and mineral salts, though other ingredients, such as fruits, can be added, thus giving rise to another version of mead known as melomel. Research has shown that fruity drinks have good consumer acceptability due to their alcohol content and their characteristic sweetness. Thus, the study aimed to produce mead with the addition of cupuaçu pulp and two different strains of Saccharomyces cerevisiae and Saccharomyces bayanus (T-58 and Red Star respectively), in order to perform a kinetic analysis of the fermentative process. For the elaboration of the mead, honey from the western honey bee (Apis melifera), cupuaçu pulp and yeasts were used, and the fermentation process lasted 15 days. The product was characterized through physicochemical and microbiological analyses. These analyses showed that the product is within the standards required by current Brazilian legislation. The monitoring of the kinetics of the mead fermentation allowed us to determine that the optimal time for this process is around 12 days, which is the point where there is a stabilization of the two strains in relation to the consumption of soluble solids and an increase in alcohol content. The two strains seem to be suitable for the production of mead; however, the results produced differ in alcohol content, resulting in drinks with distinct organoleptic characteristics.
\end{abstract}

Keywords: Mead; Cupuaçu; Yeast; Kinetics.

\section{Resumo}

O Hidromel é historicamente uma das bebidas mais antigas do mundo, tendo seu teor alcoólico variando de 4 a 14\%. Onde contêm na sua formulação basicamente mel, água, levedura e sais minerais, podendo ser adicionado outros ingredientes, como por exemplo frutas, dando origem assim a outro seguimento do hidromel chamado melomel. É comprovado por estudos anteriores, que as bebidas frutadas tem uma boa aceitabilidade pelo mercado nacional por conta de seu teor alcoólico e sua doçura característica. Desta forma o estudo objetivou a produção de hidromel com acréscimo de polpa de cupuaçu integral a partir de duas cepas diferentes de Saccharomyces cerevisiae e Saccharomyces bayanus (T-58 e Red Star respectivamente), com intuito de fazer a análise cinética do processo fermentativo. Para a elaboração do hidromel utilizouse mel de abelha Apis melífera africanizada, polpa integral de cupuaçu e as leveduras, o processo de fermentação teve duração de 15 dias. O produto foi caracterizado através de análises físico-químicas e microbiológicas. As análises físicoquímicas e microbiológicas mostraram que o produto está dentro dos padrões exigidos pela Legislação Brasileira vigente. O acompanhamento da cinética da fermentação do hidromel permitiu identificar que o tempo ótimo para esse processo fica em torno de 12 dias, onde há uma estabilização das duas cepas em relação ao consumo de sólidos solúveis e aumento de 
teor alcoólico. As duas cepas parecem ser adequadas para a produção de hidromel, no entanto, elas diferem quanto ao teor alcoólico, produzindo bebidas com características organolépticas distintas.

Palavras-chave: Hidromel; Cupuaçu; Levedura; Cinética.

\section{Resumen}

El hidromiel es históricamente una de las bebidas más antiguas del mundo, por tener su contenido de alcohol variando de 4 a 14\%. Contiene en su formulación básicamente miel, agua, levadura, sales minerales, pudiéndose adicionar otros ingredientes como, por ejemplo, frutas, dando origen a otro seguimiento de hidromiel llamado melomiel. Está probado por estudios anteriores, que las bebidas frutadas tienen una buena aceptabilidad en el mercado nacional por cuenta de su contenido de alcohol y su dulzor característico. De esta forma el estudio justificó la producción de hidromiel con la adición de la pulpa de cupuaçu integral a partir de dos cepas diferentes de Saccharomyces cerevisiae y Saccharomyces bayanus (T58 y Red star respectivamente) con el intuito de hacer el análisis cinético del proceso de fermentación. Para la elaboración de hidromiel se utilizó la miel de la abeja Apis melífera africanizada, pulpa integral de cupuaçu y las levaduras, el proceso de fermentación tuvo duración de 15 días. El producto fue caracterizado por medio de análisis fisicoquímico y microbiológico. Los análisis fisicoquímico y microbiológico mostraron que el producto está dentro del estándar exigido por la Legislación Brasileña actual. El acompañamiento de la cinética de fermentación de hidromiel permitió identificar que el tiempo hábil para este proceso está en torno de 12 días, donde hay una estabilización de dos cepas en relación al consumo de sólidos solubles y aumento de su contenido de alcohol. Las dos cepas parecen ser adecuadas para la producción de hidromiel, sin embargo, ellas difieren en el contenido de alcohol, produciendo bebidas con características organolépticas diferentes.

Palabras clave: Hidromiel; Cupuaçu; Levadura; Cinético.

\section{Introduction}

According to the Brazilian Health Regulatory Agency (Anvisa, 1978), honey is the natural product made by bees from the nectar of flowers and/or saccharine exudates of plants and can be classified according to the origin and the method used to obtain it. As for its origin, it is divided into floral honey and honeydew or honeydew honey. Floral honey is obtained from the nectars of flowers and can be subdivided into unifloral or monofloral, when extracted from flowers of the same family, genus or species, and into multifloral or polyfloral, when created with nectars of several flowers (Okaneku, 2020). Honeydew or honeydew honey is honey obtained mainly from other living parts of plants or from excretions on plants from sucking insects (Brasil, 2000).

Mead is considered the oldest known drink (Aquarone et al., 1983) and according to Brazilian Law Decree No. 6871 of July $4^{\text {th }}, 2009$, it is a beverage with an alcoholic degree of 4 to $14 \%$ by volume, $20{ }^{\circ} \mathrm{C}$, obtained by alcoholic fermentation of a bee honey solution, nutrient salts and drinking water (Brasil, 2009). In addition to this basic formulation, the mash, as this mixture is called, can have herbs and/or fruits added, thus generating fermented drinks of the most varied colors and flavors (Vargas \& Gulling, 1999; Schramm, 2003).

Fermented fruit drinks are promising products, as a number of acceptance surveys have already shown. Many European countries produce several fermented products using the same manufacturing process, and fruits such as apple, pear, blackcurrant, raspberry and cherry are the most used. In tropical countries, fruits, such as orange, pineapple, mango and cashew apples, produce fermented drinks that are quite appreciated and tasty (Muniz et al., 2002).

Brazil is one of the countries with the highest production of fruits in the world; however, post-harvest waste of some crops generates many losses. Thus, there is a need to develop technological processes that allow the reduction of post-harvest losses and at the same time provide an increase in income for the rural producer (Dias et al., 2003; Gomes, 2007).

Fruits from the northern region of Brazil, such as cupuaçu, can be added to the mash of the mead; however, there is little scientific information in regards to this. According to Melo, 2020, the lack of scientific papers related to the behavior of the fluids of cupuaçu shows a lack of technical information related to production, storage and distribution patterns, thus hindering the process of industrialization of this product.

Cupuaçu is one of the most important typically Amazonian fruits. Its economic value lies in the pulp, which is consumed in the form of juice, nectar, yogurt, ice cream, cream, liqueur, pies, jams, compotes, biscuits, and other sweets, which, for the most part, are processed by hand, on small-scale production. (Cohen \& Jackix, 2005). Due to its characteristics of high vitamin C content 
and its strong anti-inflammatory action, cupuaçu can be considered beneficial to human health and of great importance in the diet.

Regarding the analysis and quality indices of mead intended for human consumption, the Brazilian Normative Instruction $n^{\circ} 34$ of November $29^{\text {th }}, 2012$, established by the Ministry of Agriculture, Livestock and Supply (MAPA), determines the sensory, physicochemical characteristics (maturity, purity, deterioration) that the mead must contain, as well as its macroscopic and microscopic criteria, which are listed in Table 1.

Table 1 - Characteristics of the mead and its respective physicochemical limits.

\begin{tabular}{ll}
\hline Analysis & Limits and values \\
\hline Physicochemical characteristic & Lower limit 30 \\
\hline Fixed acidity $(\mathrm{mEq} / \mathrm{L})$ & Lower limit $50 / \mathrm{Upper} \mathrm{limit} 130$ \\
Total acidity $(\mathrm{mEq} / \mathrm{L})$ & Upper limit 20 \\
Volatile acidity $(\mathrm{mEq} / \mathrm{L})$ & Upper limit 0.35 \\
Total sulphur dioxide $(\mathrm{g} / \mathrm{L})$ & Lower limit 1.5 \\
Ashes $(\mathrm{g} / \mathrm{L})$ & Upper limit 0.5 \\
Total chlorides $(\mathrm{g} / \mathrm{L})$ & Lower limit 7 \\
Dry extract $($ reduced $)(\mathrm{g} / \mathrm{L})$ & Lower limit $4 / \mathrm{Upper} \mathrm{limit} 14$ \\
Alcoholic content $(\mathrm{v} / \mathrm{v})$ & Upper limit 3 \\
Sugar content $(\mathrm{g} / \mathrm{L})$ & \\
\hline
\end{tabular}

Source: Brasil. Normative Instruction n ${ }^{\circ} 34$ of November 29 (2012).

The current precarious reality experienced daily by small beekeepers of communities in Brazil's large national territory reflects the importance of seeking viable alternatives of production. This can add value to their products and contribute with technical elements aimed at enriching information for the scientific community in relation to honey processing, and the proposal of a new product for marketing also contributes to the generation of income and improvement of the quality of life of producers. This same benefit can also ximprove the lives of fruit producers who suffer from the same precarious reality.

\section{Materials and Methods}

For the production and characterization of the mead, we employed the methodology adopted by Mattietto et al. (2006) and Oliveira (2020), with some modifications. The research was developed in the Laboratory of Applied Thermodynamics of the Faculty of Agricultural Sciences at the Federal University of Amazonas, where the fermentative tests were carried out. The honey was acquired from the company Feira do Mel Flor do Amazonas, which is a small honey processing company, and the fresh cupuaçu pulp was obtained in a street market in the city of Manaus. T-58 and Red Star yeast were acquired from the manufacturer Fermentis.

The process for the production of the mead is presented in the flowchart of Figure 1.

Figure 1. Flow chart showing the process of mead production. 


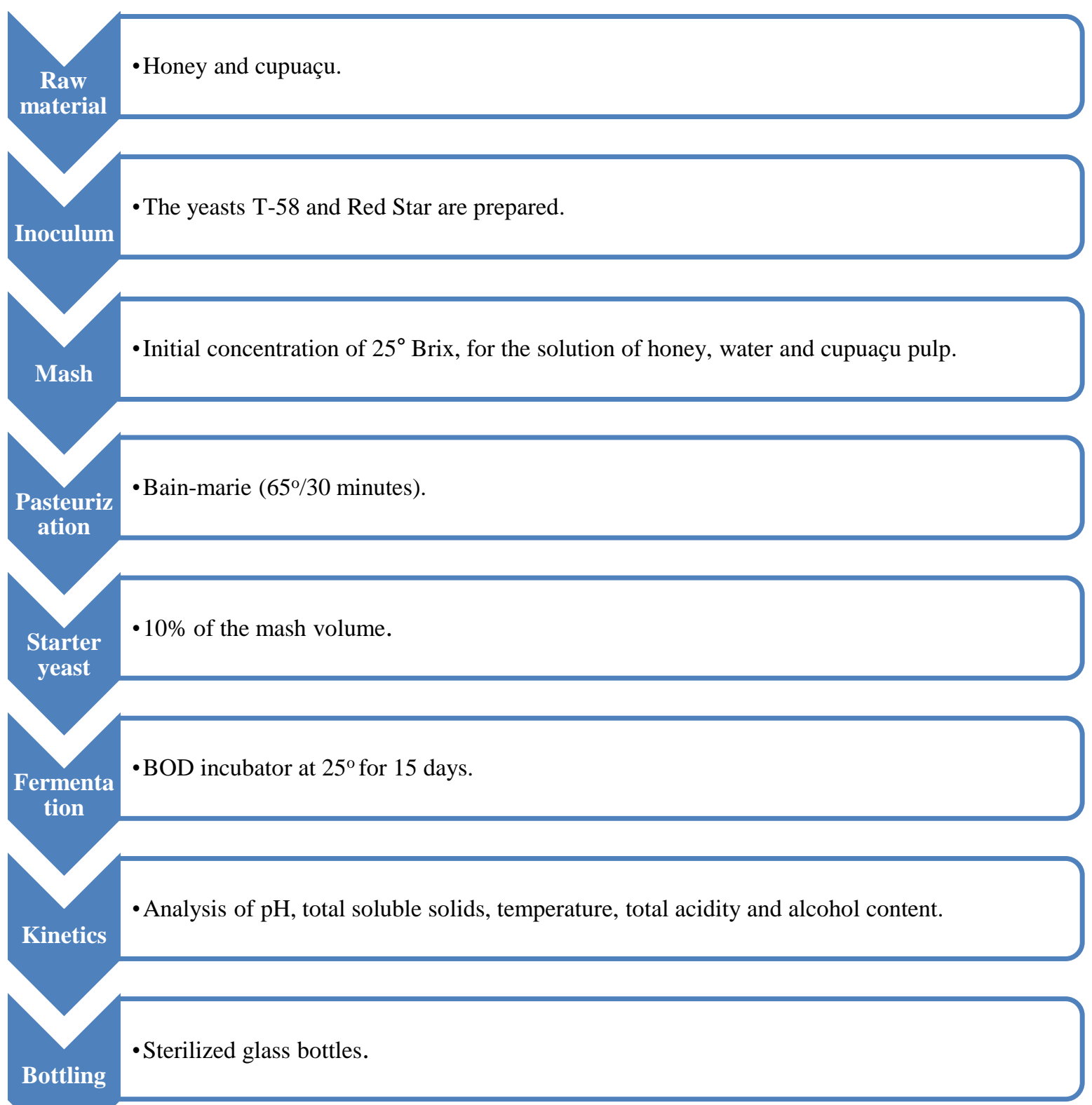

Source: Authors.

- Manufacturing of the mead: Obtaining the mead follows similar procedures to the making of wine from grapes, with the operations of preparation and correction of the mash, preparation of the starter yeast, inoculation of yeasts, fermentation and bottling.

- Cleaning of the materials: Wash all containers, bottles, spatulas, funnels, etc. with water and detergent. After rinsing, a $70 \%$ alcohol solution is prepared that is sprayed onto all utensils and the materials are left in a sterile environment until dry.

- Preparation of the inoculum: The two yeasts (dehydrated) were started according to the instructions of each supplier by incorporating water at the respective indicated temperature.

- Preparation of the mash: First, the cupuaçu pulp was diluted in mineral water at the ratio of $1 \mathrm{~kg}$ of pulp to $3 \mathrm{~L}$ of water. Later this juice was mixed with honey, until it reached the ratio of $25^{\circ}$ Brix, with a density of 1.100 . For this, the quantity of $4 \mathrm{~L}$ of mash to be produced was stipulated, measuring the initial ${ }^{\circ}$ Brix of the honey with a manual refractometer with a scale from 0 to $32^{\circ}$ Brix. Subsequently, all the mash was placed in a bain-marie at $65^{\circ} \mathrm{C}$, for $30 \mathrm{~min}$. 
- Preparation of the starter yeast: Drinking water, which corresponded to $10 \%$ of the mash, was pasteurized at $65^{\circ} \mathrm{C}$ for $30 \mathrm{~min}$. The aliquot was cooled and the yeast was added only when the temperature reached a value of less than $30^{\circ} \mathrm{C}$. The ratio of $0.25 \mathrm{~g}$ per liter of Saccharomyces cerevisiae and Saccharomyces bayanus was used, both in different containers. After pasteurizing, the starter yeast was maintained at $20^{\circ} \mathrm{C}$ for $5 \mathrm{~min}$, in closed containers.

- Fermentation: The fermentation process consisted of the mash at a temperature of $21^{\circ} \mathrm{C}$, then the yeast was added and mixed in two separate containers both with $4 \mathrm{~L}$ of mash. Subsequently, the mash was transferred to four bioreactors with the amount of $2 \mathrm{~L}$ of mash in each, two bioreactors with the yeast Saccharomyces cerevisiae and two with the yeast Saccharomyces bayanus. The fermentation process lasted for 15 days and was monitored daily, and the process was stopped when the soluble solids content ( $\left.{ }^{\circ} \mathrm{Brix}\right)$ stabilized. This process of interruption consisted in the rapid cooling of this mash, which involved subjecting the mash to a temperature of $3{ }^{\circ} \mathrm{C}$ for $6 \mathrm{~h}$, in order to deactivate the fermentation process of the yeasts.

- Transfer: The mead was transferred to another sanitized carboy to prevent it from coming into contact with the sediments that had formed.

- Bottling and pasteurization: The clarified mead was decanted into glass bottles that had been previously sanitized. The bottled product was pasteurized in a water bath at a temperature of $65^{\circ} \mathrm{C}$ for $30 \mathrm{~min}$, in order to cease fermentation and eliminate possible pathogenic microorganisms. After pasteurization, the mead was cooled in running water and stored at room temperature.

- Kinetics of fermentation: The fermentative process was monitored throughout the whole time by determining the $\mathrm{pH}$, the total titratable acidity, the total soluble solids $\left({ }^{\circ} \mathrm{Brix}\right)$, and the alcoholic content $\left({ }^{\circ} \mathrm{GL}\right)$. The analyses were carried out daily until the end of fermentation following the methodology of the Adolfo Lutz Institute (2008).

- Physicochemical analysis: Once the finished product was obtained, the fermented product was analyzed for alcohol, $\mathrm{pH}$, total titratable acidity, and total soluble solids ( ${ }^{\circ}$ Brix), following the methodology of the Adolfo Lutz Institute (2008).

- Microbiological analysis: After the completion of the product, microbiological analyses were performed (in triplicate) on the samples of the two yeasts in order to show the presence or not of total coliforms, thermotolerant coliforms and Salmonella spp. 


\section{Results and Discussion}

\subsection{Physicochemical analysis of fermentation kinetics}

Figure 2. Consumption of total soluble solids during fermentation of the mead in the yeasts Saccharomyces cerevisiae and Saccharomyces bayanus.

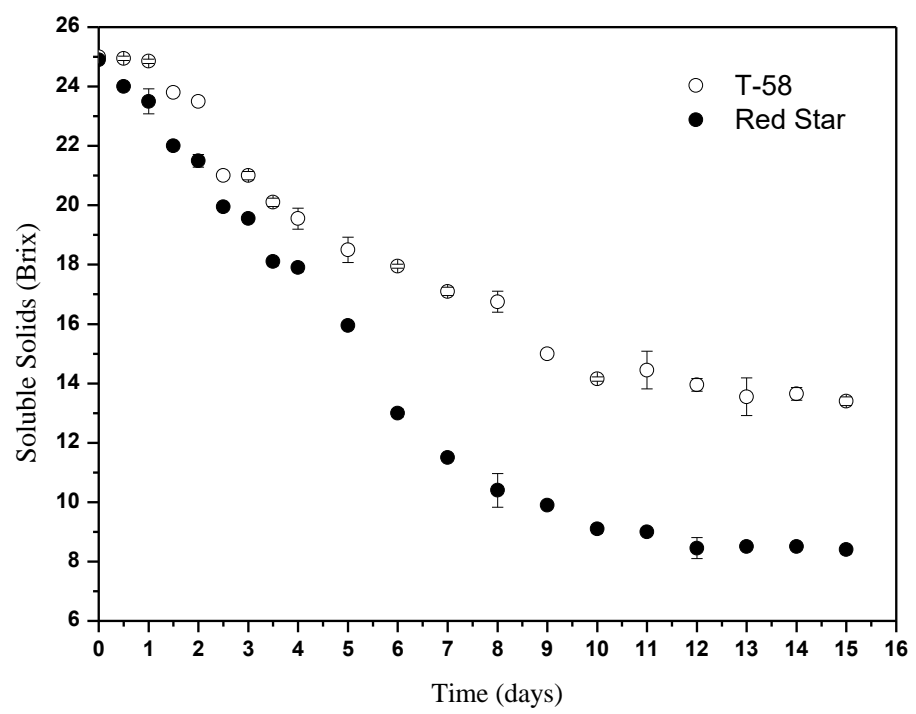

Source: Authors.

The results of the ${ }^{\circ}$ Brix analyses of the two yeasts during fermentation are shown in Figure 2. The fermentation stage lasted 15 days and the final fermentation time was determined according to the stabilization of the parameters of the soluble solids content $\left({ }^{\circ}\right.$ Brix). During the fermentation process, it was possible to identify that there was a change in the value of the initial ${ }^{\circ}$ Brix, since during the process there was a decrease in total soluble solids (TSS) and consequently an increase in the alcohol content due to the consumption of the substrate by the yeasts. This transformation of sugar into alcohol, identified by the reduction of soluble solids also occurred in the fermentation carried out by Costa (2016), where the content of soluble solids reduced from 24.6 to $10.9{ }^{\circ}$ Brix for the traditional mead and from 24 to $10.2^{\circ}$ Brix for the strawberry flavored mead. A very high ${ }^{\circ}$ Brix value causes an irregular fermentation, leaving sugars at the end of fermentation, while very low ${ }^{\circ}$ Brix values cause a low efficiency in the process since sugar is the food base of the yeast (Queiroz et al., 2014).

Given the data shown in Figure 2, we can identify the gradual decrease of sugars, which are within the parameters proposed for the production of a mead with the addition of fruit (melomel). The presence of three regions can be identified in the graph. In the first region refers to the first two days (from day 0 to day 2), at the beginning of the fermentation process, which is characterized by adaptation of yeast. The starter yeasts were added to the mash in order to start the fermentation process. It is observed in this step that although both experiments started with $25^{\circ}$ Brix, in the experiment with the yeast Saccharomyces bayanus, there was a rapid decline in soluble solids, showing that the starter yeast performed efficiently. However, with the yeast Saccharomyces cerevisiae, it is possible to identify the adaptation phase, which is probably due to the specific characteristics of the yeast.

In the second region, which lasts until day 10, there is a rapid consumption of soluble solids, which is identified as an exponential phase, and is where the maximum speed of conversion of sugar into ethanol is achieved, probably due to the higher concentration of yeasts in the medium. In this phase, the process with the yeast Saccharomyces bayanus is more efficient in relation to sugar consumption than with Saccharomyces cerevisiae. 
In the third region (from 10 to 15 days), stagnation of sugar consumption is observed, characterizing the stationary phase, probably due to a higher concentration of alcohol in the medium or the lower amount of nutrients available, thus limiting the population's capacity for growth. According to Dantas and Silva (2017), the constancy in the content of total soluble solids is an indication of the end of fermentation. This phase is easily observed in the graphs for both of the yeasts. As we can see, the loss of soluble solids occurs, which in other words would be the fermentation process, where it is a complex chain of reactions where the yeasts transform the sugar molecules into two simpler molecules: one of ethanol (alcohol) and another in carbon dioxide $\left(\mathrm{CO}_{2}\right)$. After this transformation process, we were able to notice the reduction of sugar levels and consequently the production of the mead.

In the acidity chart (Figure 3), the total acidity of the mead was $58.45 \pm 2.61 \mathrm{mEq} / \mathrm{L}$ for Safale T-58 yeast and $73.81 \pm 3.93$ $\mathrm{mEq} / \mathrm{L}$ for Red Star yeast. This parameter is in accordance with the minimum and maximum limits required by the legislation, which are from 50 to $130 \mathrm{mEq} / \mathrm{L}$ (Brasil, 2012). For fermented beverages, the total acidity is always related to the $\mathrm{pH}$, since it corresponds to the amount of all acids present. We can note that from the $10^{\text {th }}$ day, the value of acidity does not undergo much variation, thereby characterizing the state of maturation of the drink. This behavior may be associated with the metabolism of yeasts, which release organic acids during the fermentation process (Jones et al., 1981).

Figure 3. Evolution of total acidity during fermentation of mead with the yeasts Saccharomyces cerevisiae and Saccharomyces bayanus.

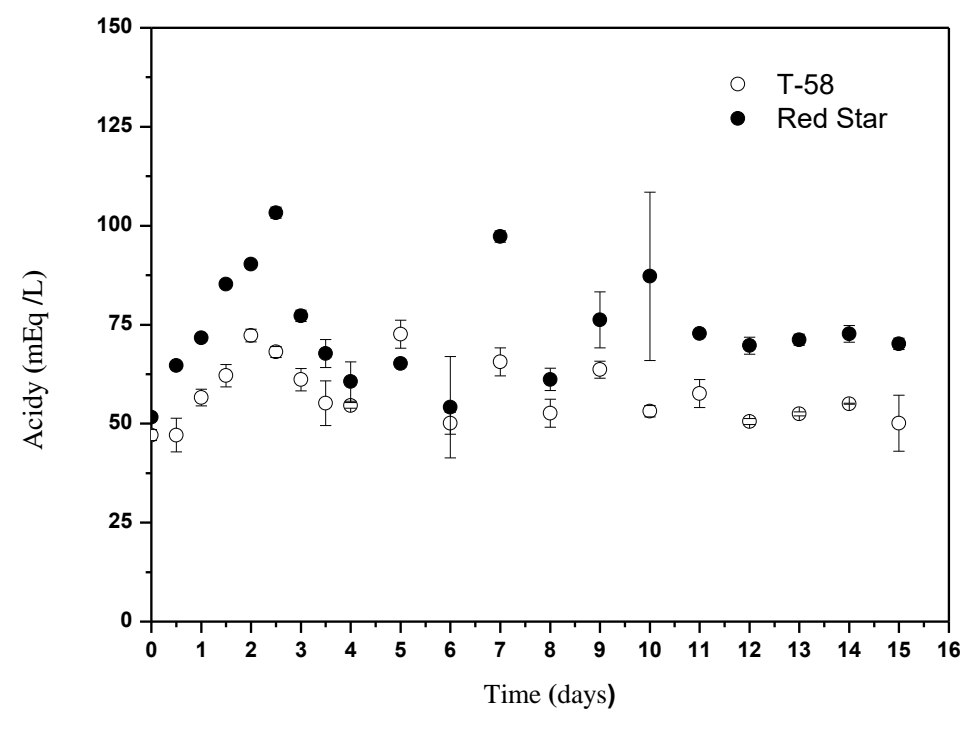

Source: Authors.

In Figure 4, we were able to identify the $\mathrm{pH}$ values related to the fermentative process of the mead. In relation to $\mathrm{pH}$, most of the yeasts used in fermentative processes have some resistance to low $\mathrm{pH}$ levels, since the predominant $\mathrm{pH}$ in fermentations varies between 4 and 5.5. In the case of T-58 yeast, we reached the average value of $4.975 \pm 0.00$ and Red Star yeast's average was 4.672 \pm 0.03 , which is within the values stipulated for fermented beverages. Experiments confirm that the more acidic the mash, the higher the productivity, since bacteria and other contaminants do not survive in low $\mathrm{pH}$ media (about 3 to 4 ) and the generation of glycerol as a complementary component of fermentation is greatly reduced in acidic media (Jean, 2010). 
Figure 4. pH evolution during fermentation of mead with the yeasts Saccharomyces cerevisiae and Saccharomyces bayanus.

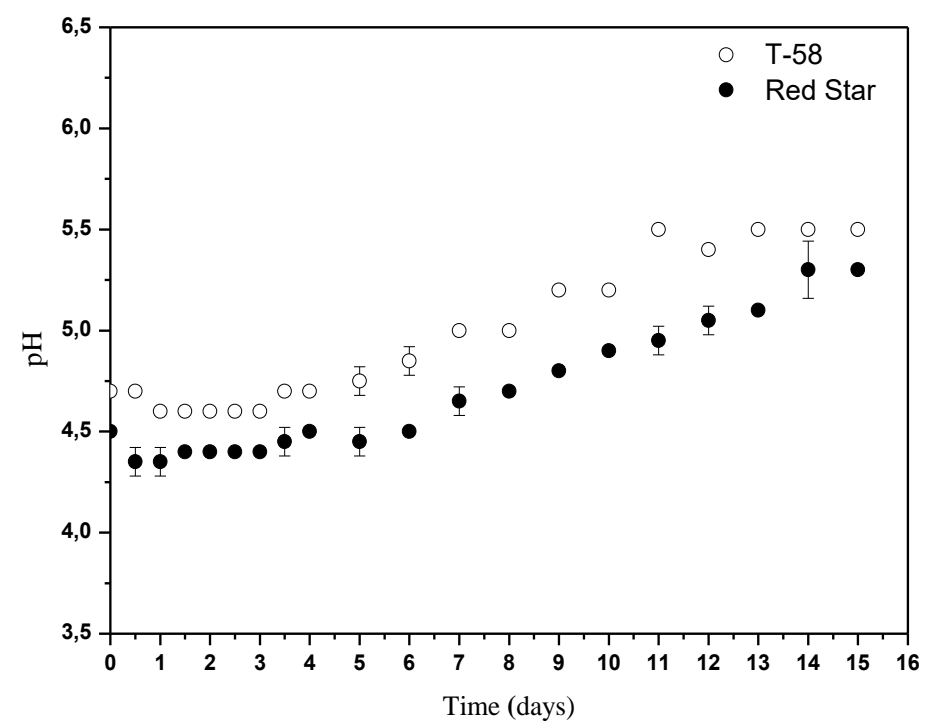

Source: Authors.

In Figure 5, it is possible to observe the curve of the alcohol content of the two yeasts as a function of time in days, and we note an almost linear growth during the days studied. The final alcohol content found for T-58 yeast was 6.26\%, and for Red Star yeast it was $8.92 \%$. The graph also indicates that when reaching the $13^{\text {th }}$ day of fermentation the ethanol values begin to present a trend towards stabilization. The values obtained are within the limits established by the legislation that allows a content of 4 to $14 \%$ by volume (Brasil, 2009).

Figure 5. Evolution of the alcoholic content during the fermentation of mead with the yeasts Saccharomyces cerevisiae and Saccharomyces bayanus.

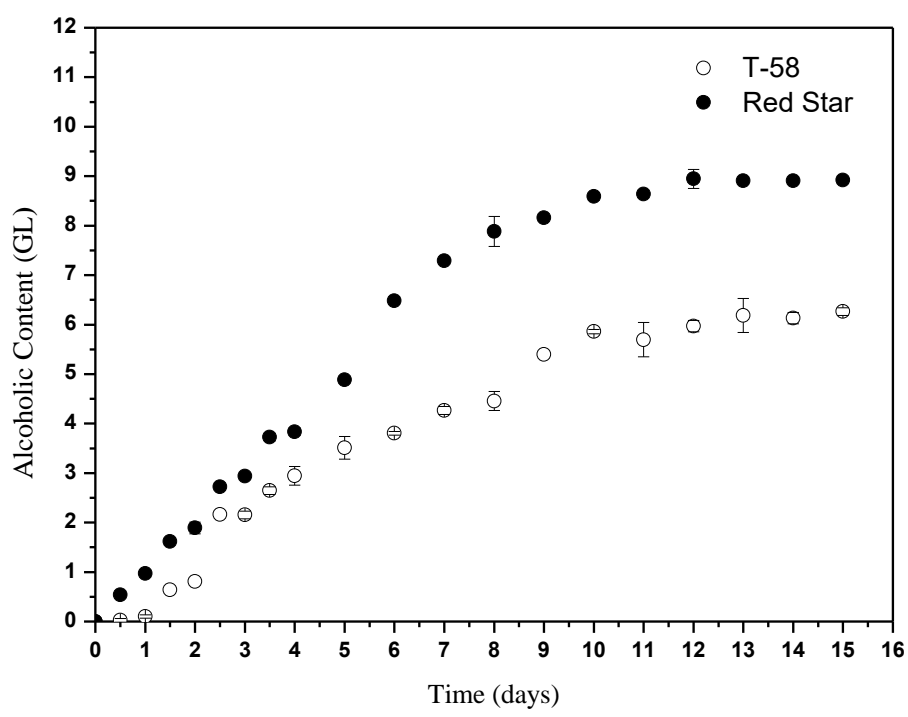

Source: Authors. 
Physicochemical analysis of the final fermentation with the yeasts Saccharomyces cerevisiae and Saccharomyces bayanus

The physicochemical analyses performed with the yeasts T-58 and Red Star demonstrate that the product, both with an initial ${ }^{\circ}$ Brix of 25, are in compliance with established Normative Instruction No. 34, of November 29th, 2012, which establishes the complementation of identity and quality standards for fermented beverages, seen in Table 2 (Brasil, 2012).

Table 2. Physicochemical characterization of mead produced with two different strains of yeast.

\begin{tabular}{|c|c|c|c|}
\hline Parameter & T-58 & Red Star & Brasil, 2012 \\
\hline $\begin{array}{c}\text { Alcoholic content }(\% \\
\text { v/v) }\end{array}$ & $6.26 \pm 0.07$ & $8.92 \pm 0.05$ & $4-14(\% \mathrm{v} / \mathrm{v})$ \\
\hline Total acidity (mEq/L) & $50.12 \pm 7.06$ & $62.17 \pm 1.44$ & $\begin{array}{l}50-130 \\
(\mathrm{mEq} / \mathrm{L})\end{array}$ \\
\hline $\mathrm{pH}$ & $5.5 \pm 0.00$ & $5.3 \pm 0.00$ & - \\
\hline $\begin{array}{l}\text { Total soluble solids } \\
\qquad\left({ }^{\circ} \text { Brix }\right)\end{array}$ & $13.4 \pm 0.14$ & $8.4 \pm 0.14$ & - \\
\hline
\end{tabular}

Note: The results represented here refer to means of the determinations performed in duplicate, followed by the respective standard deviation.

Source: Authors.

According to the results of the analysis of the physicochemical characteristics of the mead samples (Table 2), the variables of total acidity, $\mathrm{pH}$, soluble solids and alcohol content showed a significant difference due to the influence of the specific characteristics of the two different yeasts used on the level of these components. For the alcohol content, the value found for T-58 yeast was $6.26^{\circ} \mathrm{GL}$ and for Red Star yeast it was $8.92^{\circ} \mathrm{GL}$, which is in compliance with the legislation that allows a content of 4 to $14 \%$ by volume (Brasil, 2009). Ethyl alcohol is the most relevant product of the fermentation process, and makes up about $95 \%$ of the alcohols formed in fermentation. Other alcohols such as isobutyl, isoamyl, among others, are present in a smaller proportion, (Dantas \& Silva, 2017).

Regarding the total acidity found, the two meads, either with T-58 yeast or with Red Star yeast, present the values of 50.12 and $62.17 \mathrm{mEq} / \mathrm{L}$, respectively, and are in accordance with the levels established by Normative Instruction No. 34, and in accordance with the values in the legislation for mead, which allow a minimum content of $50 \mathrm{mEq} / \mathrm{L}$ and maximum of $130 \mathrm{mEq} / \mathrm{L}$ (Brasil, 2012). It is of paramount importance to control the acidity level during and after the fermentation process process, since it can directly influence the organoleptic properties of the mead.

$\mathrm{pH}$ is an important factor that influences acidity. The $\mathrm{pH}$ value of fermented honey is 3.45 , according to studies conducted for mead. According to Oliveira (2020), the $\mathrm{pH}$ of the experiments with 30, 25 and $20{ }^{\circ}$ Brix stabilized around 3.5, 2.8 and 2.8, respectively. The $\mathrm{pH}$ results found in these analyses were 5.5 and 5.3, diverging from the values found in the literature, probably due to the use of a fruit in the process or due to the characteristics of the yeasts used.

\subsection{Microbiological Analyses}

The results of microbiological analyses for the detection of Salmonella and coliforms (Table 3) showed that these were in accordance with the current Brazilian legislation, which establishes the absence of Salmonella in food and a maximum limit of $5 \mathrm{x}$ $10^{2}$ coliforms at $45^{\circ} \mathrm{g}$ of the samples according to Resolution - RDC No. 12 of January $2^{\text {nd }}$, 2001, of the National Agency for Sanitary Surveillance (ANVISA), since no such agents were found in the samples. 
Table 3. Microbiological analyses of honey fermented in different concentrations.

\begin{tabular}{ccc}
\hline \multirow{2}{*}{ Analysis } & \multicolumn{2}{c}{ Results } \\
\cline { 2 - 3 } & $\begin{array}{c}\text { Saccharomyces } \\
\text { cerevisiae }\end{array}$ & $\begin{array}{c}\text { Saccharomyces } \\
\text { bayanus }\end{array}$ \\
\hline Total coliforms & $<3 \mathrm{MPN} / \mathrm{ml}$ & $<3 \mathrm{MPN} / \mathrm{ml}$ \\
Thermotolerant coliforms & $<3 \mathrm{MPN} / \mathrm{ml}$ & $<3 \mathrm{MPN} / \mathrm{ml}$ \\
Salmonella spp. & Absent & Absent \\
\hline
\end{tabular}

Source: Authors.

The results showed that the two meads produced with two different strains of yeast were elaborated under adequate sanitary conditions, due to the absence of the microorganisms studied, thus meeting resolution RDC No. 12, of January $2^{\text {nd }}$, 2001, which determines the technical regulations for microbiological standards for food (Brasil, 2001).

\section{Conclusion}

We evaluated the production and characterization of mead with addition of cupuaçu pulp from S. cerevisiae (T-58) and S. bayanus (Red Star). The physicochemical and microbiological parameters of the beverage were within the specifications required by Brazilian legislation for alcoholic drinks. The kinetics of the fermentation process allowed us to infer that the optimal time for fermentation is around 12 days.

The two strains used proved to be suitable for the production of mead, and produced slightly different drinks in terms of physicochemical properties. The mead produced from the T-58 strain, had $25^{\circ}$ Brix (initial), had a total acidity of $50.12 \mathrm{mEq} / \mathrm{L} ; \mathrm{pH}$ of $5.5 ; 13.4^{\circ}$ Brix (final) and an alcohol content of $6.26 \% \mathrm{v} / \mathrm{v}$. The mead produced from the Red Star strain, had $25^{\circ}$ Brix (initial), had total acidity of $62.17 \mathrm{mEq} / \mathrm{L}$; $\mathrm{pH}$ of $5.3 ; 8.4^{\circ}$ Brix (final) and an alcohol content of $8.4 \% \mathrm{v} / \mathrm{v}$. The microbiological analysis of the mead samples ensured that good handling and manufacturing practices were respected and demonstrated that the product was in compliance with the Brazilian legislation regarding the presence of Salmonella spp. and coliforms.

More technical and scientific studies can and need to be carried out in relation to this matter, since the results obtained here suggest that the production of mead with the addition of cupuaçu proved to be very efficient, bringing alternatives to add value to the raw material and proposing a new product for marketing.

\section{Acknowledgments}

I first thank God for giving me this opportunity to pass the knowledge on to others. The Federal University of Amazonas for providing the structure and research grant, to the Laboratory of Applied Thermodynamics - UFAM, to my advisor and friend Dr. Wenderson Gomes and Dr. Antonia Queiroz for their research assistance.

\section{References}

Alves, E. M., Toledo, V. A. A., Marchini, L. C., Sereia, M. J., \& Moetia, C. C. C. (2009). Presença de coliformes, bolores e leveduras em amostras de mel orgânico de abelhas africanizadas das ilhas do alto rio Paraná. Ciência Rural, 39 (7), 2222-4.

Aquarone, E., Borzani, W., Schimidell, W., \& Lima, U (2001). Biotecnologia na produção de alimentos. Edgard Blücher. 523p.

Brasil. (2001). Agência Nacional de Vigilância Sanitária - Anvisa. Ministério da Saúde Resolução RDC nº 12 , de 02 de janeiro 2001 , que aprova o Regulamento Técnico sobre Padrões Microbiológicos para Alimentos. Diário Oficial da União, Brasília, DF.

Brasil. (1978). Agência Nacional de Vigilância Sanitária - Anvisa. Resolução CNNPA nº 12 de 1978. http://www.anvisa.gov.br/anvisalegis/resol/12_78_mel.htm.

Brasil. (2009). Ministério da Agricultura, Pecuária e Abastecimento. Dispões sobre a padronização, a classificação, o registro, a inspeção, a produção e a fiscalização de bebidas (Lei n ${ }^{\circ}$ 8918, de junho de 1994). (2009). Diário Oficial da República Federativa do Brasil.

Brasil. (2000). Ministério da Agricultura, Pecuária e Abastecimento - Mapa. Instrução Normativa n 11 de 20 de outubro de 2000 . Aprova o Regulamento Técnico de Identidade e Qualidade do Mel. Diário Oficial da União - DOU. 
Brasil. (2012). Ministério da Agricultura, Pecuária e Abastecimento - Mapa. Portaria no 34 de 29 de novembro de 2012. Aprova as Normas Higiênico-Sanitárias e Tecnológicas para Hidromel. Diário Oficial da União - DOU.

Cohen, K. O., \& Jackix, M. N. H. (2005). Estudo do liquor de cupuaçu. Ciênc. Tecnol. Aliment. 25(1), 182-90.

Costa, A. M. G. et al. (2016). Caracterização e Análise Sensorial de Hidromel: Tipo Seco Tradicional e Saborizado com Morango. XXV Congresso Brasileiro de Ciência e Tecnologia de Alimentos, Gramado - RS.

Dantas, C. E. A., \& Silva, J. L. A. (2017). Fermentado alcoólico de Umbu: Produção, Cinética de fermentação, e caracterização físico-química. HALOS. Currais Novos - RN.

Decreto $n^{\circ}$ 6871. Decreto $N^{\circ}$ 6.871. (2009), de 4 de junho de 2009. Regulamenta a Lei no 8.918, de 14 de julho de 1994.

Dias, D. R., Schawn, R. F., Lima, L. C. O. (2003). Metodologia para elaboração de fermentado de cajá (Spondias mombin L.). Ciência e Tecnologia de Alimentos. 23(3), 342 .

Gonçalves, A. L., \& Alves Filho, A. (2005). Atividade antimicrobiana do mel de abelha nativa sem ferrão Nannotrigona testaceicornis (Hymenoptera: Apidae, Meliponini). Arquivos do Instituto de Biologia, 72 (4), 455-59.

Instituto Adolfo Lutz. (2008). Métodos físico-químicos para análise de alimentos. Edição 4, 1020 p.

Jones, R. P., Pamment, N., \& Greenfield, P. F. (1981). Alcohol fermentation by yeasts. The effect of environmental and other variables. Process Biochemistry, 16, $42-9$.

Lino, T. A. L. R. (2006). Alcoolismo - da causa à doença. http://www.psicologia.com.pt/artigos/ver_artigo_licenciatura.php?codigo=TL0054 .

Mattietto, R. A., Lima, F. C. C., Venturieri, G. C., \& Araujo, A. A. (2006). Tecnologia para obtenção artesanal de Hidromel do tipo doce. Embrapa. Comunicado Técnico 170, 1-5.

Melo, F. S. (2020). Avaliação reológica da polpa e concentrado de cupuaçu (Theobroma grandiflorum schum). Braz. J. of Develop., 6(7), 45182-92.

Muniz, C. R., Borges, M. F., Abreu, F. A. P., Nassu, R. T., \& Freitas, C. A. S. (2002). Bebidas fermentadas a partir de frutos tropicais. Boletim do CEPPA, 20(2), $309-22$.

Oliveira, I. V. (2020). Produção e caracterização do hidromel tipo doce. Braz. J. of Develop., 6(3), 11176-91.

Okaneku, B. M. (2020). Análise físico-química e microbiológica do mel de abelhas africanizadas (apis mellifera). Braz. J. of Develop., 6(4), 18607-20.

Queiroz, J. C. F. et al. (2014). Produção de Hidromel de Forma Artesanal e Avaliação dos Parâmetros durante o Processo Fermentativo. Revista Saúde e Ciência, Campina Grande.

Scharamm, K. (2003). The complete meadmaker: home production of honey wine from your first batch to award-winning fruit and herb variations. United States: Brewers publications.

Teramoto, Y., Sato, R., \& Ueda, S. (2005). Characteristics of fermentation yeast isolated from traditional Ethiopian honey wine, ogol. African Journal of Biotechnology, 4(2), 160-63.

Tuse, D. (1994). Single cell protein: current status and future prospects. Food Science, 19(4), 273-325. 